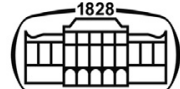

AKADÉMIAI KIADÓ

Acta Veterinaria

Hungarica

69 (2021) 1, 31-37

DOl:

$10.1556 / 004.2021 .00007$

(C) 2021 The Author(s)

\title{
The first serological evidence of Anaplasma phagocytophilum in horses in Slovakia
}

MONIKA DRÁŽOVSKÁ ${ }^{1}$, BORIS VOJTEK ${ }^{1 *}$ JANA MOJŽIŠOVÁ ${ }^{1}$, SIMONA KOLENIČOVÁ ${ }^{1}$, FILIP KOLVEK ${ }^{1}$, MARIÁN PROKEŠ ${ }^{1}$, L'UBOŠ KORYTÁR ${ }^{1}$, ALEXANDER CSANADY ${ }^{2}$, ANNA ONDREJKOVÁ ${ }^{1}$, TATIANA VATAŠČINOVÁ ${ }^{1}$ and MANGESH RAMESH BHIDE ${ }^{1}$

\author{
${ }^{1}$ University of Veterinary Medicine and Pharmacy in Košice, Komenského 73, 041 81, Košice, Slovak \\ Republic \\ ${ }^{2}$ University of Prešov in Prešov, Prešov, Slovak Republic
}

Received: 1 March 2020 - Accepted: 22 February 2021

Published online: 7 April 2021

\section{RESEARCH ARTICLE}

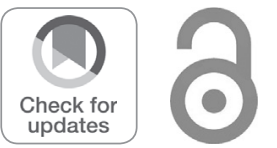

${ }^{*}$ Corresponding author. Tel.: +42 1917171064.

E-mail: boris.vojtek@uvlf.sk

\begin{abstract}
Anaplasma phagocytophilum is the causative agent of granulocytic anaplasmosis. It affects humans and several wild and domesticated mammals, including horses. The aim of our study was a preliminary survey of the occurrence of these re-emerging pathogens in horses in Slovakia. The sera from 200 animals of different ages and both sexes were tested for the presence of A. phagocytophilum antibodies by indirect immunofluorescence assay. Subsequently, detection of the $16 \mathrm{~S}$ rRNA gene fragment of $A$. phagocytophilum was attempted by polymerase chain reaction (PCR) in each blood sample. Our results confirmed the presence of specific antibodies in 85 out of 200 individuals (42.5\%), but no significant changes were found between the animals of different ages and sexes. However, the PCR analysis did not detect any positive animals. Our data represent one of the highest values of seropositivity to $A$. phagocytophilum in horses in Central Europe. These results may contribute to a better understanding of the circulation of $A$. phagocytophilum in this region, thus indicating a potential risk to other susceptible species.
\end{abstract}

\section{KEYWORDS}

equine granulocytic anaplasmosis, indirect immunofluorescence assay, Central Europe, vector-borne diseases

\section{INTRODUCTION}

As a result of the climatic and urban changes in the environment, tick-borne diseases are becoming an emerging problem in the temperate regions of Europe (Parham et al., 2015; Yang et al., 2018). Anaplasma (A.) spp. are one of the important bacterial pathogens transmitted by ticks. In Europe, Ixodes ricinus (Kiewra et al., 2014; Tomassone et al., 2018) was described as the main vector of this pathogen. Worldwide, other tick representatives of the genus Ixodes as well as the genera Dermacentor, Rhipicephalus, Amblyomma and Haemaphysalis play a key role in the transmission of anaplasmosis (Rymaszewska and Grenda, 2008). Until now, there are several known species of bacteria from the genus Anaplasma, such as A. phagocytophilum, A. marginale, A. bovis, A. platys, A. ovis, A. centrale, A. caudatum, A. odocoilei as well as the newly discovered A. capra (Tate et al., 2013; Yang et al., 2015; Dantas-Torres and Otranto, 2017; Mullen and Durden, 2018). Furthermore, a few strains were newly detected and named as 'Candidatus Anaplasma boleense', 'Candidatus Anaplasma camelii', 'Candidatus Anaplasma corsicanum', 'Candidatus Anaplasma ivorensis', 'Candidatus Anaplasma mediterraneum', 'Candidatus Anaplasma rodmosense', and 'Candidatus Anaplasma sphenisci’ (Bastos et al., 2015; Ehounoud et al., 2016; Guo et al., 2016; 
Dahmani et al., 2017; Lu et al., 2017; Vanstreels et al., 2018). The zoonotic potential of the most important species $A$. phagocytophilum and $A$. capra may represent a risk for public health in Europe (Greene, 2012). Until now, only $A$. phagocytophilum has been detected in horses. This agent invades the granulocytes of various mammalian species and is the causative agent of the tick-borne fever in ruminants, horses, dogs and humans, known as granulocytic anaplasmosis (Lotrič-Furlan et al., 2006; Passamonti et al., 2010; Król et al., 2016). The disease is characterised by high fever, depression, anorexia, icterus, ataxia, lower limb oedema, thrombocytopenia, anaemia and leukopenia in both naturally and experimentally infected horses (Bermann et al., 2002; Franzén et al., 2005). The acute infection is typical in horses, humans and mice models, while persistent infections occur in sheep, rodents and dogs (Rejmanek et al., 2012).

After reorganisation in the order Rickettsiales based on $16 S$ rRNA and GroESL gene analysis, the species A. phagocytophilum substituted the species Ehrlichia (E.) phagocytophila, E. equi and the agent of canine and human granulocytic ehrlichiosis (Dumler et al., 2001; Woldehiwet, 2010; Pishmisheva et al., 2016). A. phagocytophilum is the most prevalent species of the genus in various parts of the world depending on tick occurrence (Eisen, 2018). It was also described in animals and humans in many countries of Europe (Jahfari et al., 2014). Some studies observed coexposure to A. phagocytophilum with other serious zoonotic pathogens, especially Borrelia burgdorferi (Derdáková et al., 2011; Butler et al., 2016; Tsachev et al., 2018).

In Slovakia, specific A. phagocytophilum antibodies were detected in humans for the first time by Kalinová et al. (2009). The first clinical case of human granulocytic anaplasmosis was described by Nováková et al. (2010) in a 54-year-old man; subsequently, Kalinová et al. (2015) confirmed specific antibodies to A. phagocytophilum in 22 patients with suspected tick-borne encephalitis. However, the presence of $A$. phagocytophilum has been reported in Slovakia in $8.3 \%$ of ticks (Derdáková et al., 2003) and 3.9\% of sheep (Derdáková et al., 2011). Also, Smetanová et al. (2006) observed A. phagocytophilum in $4.4 \%$ of ticks, $5.5 \%$ of wild boars, $1 / 2$ of roe deer, $1 / 3$ of red deer and in $6 \%$ of rodents tested. Later on, Svitálková et al. (2015) demonstrated a higher rate of A. phagocytophilum infection in $I$. ricinus in an urban habitat in south-western Slovakia. The authors also suggested that rodents are not the main reservoirs of this pathogen.

Until now, only little information has been available regarding the prevalence of $A$. phagocytophilum in horses. For example, Slivinska et al. (2016) tested 39 horses from Slovakia by PCR and observed only one positive case. Since the infection is characterised by short-term bacteraemia (Passamonti et al., 2010), the detection of specific antibodies facilitates an understanding of the disease circulation.

The aim of this study was to determine and follow up the seroprevalence of A. phagocytophilum and to perform the molecular identification of this agent in horses in Slovakia.

\section{MATERIALS AND METHODS}

\section{Ethics statement}

The study was performed in compliance with the institutional guidelines for animal welfare issued by The Ethics Committee of the University of Veterinary Medicine and Pharmacy in Košice. All animal samples in this study were examined with the assistance of their owners. Blood samples were collected by a veterinarian.

\section{Blood sampling}

Ten-ml samples of venous blood were collected from the jugular vein of 200 horses without clinical signs consistent with equine granulocytic anaplasmosis at the time of sampling. The blood was collected into sterile coagulant-free tubes that facilitated coagulation and into sterile tubes with an anticoagulant. The coagulated blood was centrifuged and the obtained sera and unclotted blood were stored at $-80{ }^{\circ} \mathrm{C}$ for further tests. The horses included in this study were of both sexes (108 females and 92 males), 22 different breeds and their age ranged from a 10 days old foal to a 26 years old mare. The horses originated from 17 studs (Table 1).

\section{Characterisation of the sampling sites}

The horse studs were selected from various regions of Slovakia (Fig. 1). A large portion of Slovakia is part of the Carpathian Mountains region (Kozak et al., 2013). The average annual temperature in Slovakia is $10{ }^{\circ} \mathrm{C}$, while during the summer the average temperature increases to 26 ${ }^{\circ} \mathrm{C}$. In association with an annual average relative humidity of $60 \%$ and rainfall varying from 500 to $2000 \mathrm{~mm}$ (Onderka et al., 2020), the whole territory of Slovakia represents a very suitable biotope for tick occurrence (Bazovska et al., 2005).

\section{Serological analysis}

The sera were tested for IgG against A. phagocytophilum using the commercial A. phagocytophilum IFA Equine Antibody Kit (Fuller Laboratories, USA) based on A. phagocytophilum HE-1 isolate antigens derived from HL-60 cells. The test was performed according to the manufacturer's instructions. Briefly, all samples were tested at a titre of 1:80 as a starting dilution in phosphate-buffered saline solution (PBS) of $\mathrm{pH}$ 7.2. The samples giving a positive reaction at a titre of 1:80 were tested also at 1:160, 1:320 and 1:640. The diluted sera were placed onto the slides with $A$. phagocytophilum antigen and incubated for $30 \mathrm{~min}$ at $37^{\circ} \mathrm{C}$ in a humid chamber. After washing with PBS, anti-horse IgG conjugate was added and the slides were incubated under the same conditions. After the final wash, the PBS samples were mounted to buffered glycerol. The results were analysed using a NIKON Labophot 2A fluorescence microscope at $\times 400$ magnification. The reaction was scored positive when A. phagocytophilum morulae giving bright green fluorescence were shown, indicating the presence of specific antibodies. Samples giving a positive reaction at 1:640 were considered positive. 
Table 1. Characterisation of the horse studs

\begin{tabular}{|c|c|c|c|c|c|}
\hline Stud number & District & Location & Altitude above sea level & Season & Management method \\
\hline 1 & Trenčín & $\begin{array}{l}48^{\circ} 58^{\prime} 1.27^{\prime \prime} \mathrm{N} \\
18^{\circ} 07^{\prime} 8.11^{\prime \prime} \mathrm{E}\end{array}$ & $226 \mathrm{~m}$ & Spring & day pasture \\
\hline 2 & Trenčín & $\begin{array}{l}48^{\circ} 48^{\prime} 59.99^{\prime \prime} \mathrm{N} \\
17^{\circ} 47^{\prime} 59.99^{\prime \prime} \mathrm{E}\end{array}$ & $254 \mathrm{~m}$ & Summer & day pasture \\
\hline 3 & Rožňava & $\begin{array}{l}48^{\circ} 49^{\prime} 14.63^{\prime \prime} \mathrm{N} \\
20^{\circ} 22^{\prime} 11.57^{\prime \prime} \mathrm{E}\end{array}$ & $456 \mathrm{~m}$ & Summer & day/night pasture \\
\hline 4 & Trenčín & $\begin{array}{l}48^{\circ} 58^{\prime} 59.99^{\prime \prime} \mathrm{N} \\
18^{\circ} 08^{\prime} 60.00^{\prime \prime} \mathrm{E}\end{array}$ & $230 \mathrm{~m}$ & Autumn & day pasture \\
\hline 5 & Košice - okolie & $\begin{array}{l}48^{\circ} 35^{\prime} 59.99^{\prime \prime} \mathrm{N} \\
21^{\circ} 20^{\prime} 59.99^{\prime \prime} \mathrm{E}\end{array}$ & $181 \mathrm{~m}$ & Autumn & day/night pasture \\
\hline 6 & Zlaté Moravce & $\begin{array}{l}48^{\circ} 25^{\prime} 09.8^{\prime \prime} \mathrm{N} \\
18^{\circ} 24^{\prime} 49.1^{\prime \prime} \mathrm{E}\end{array}$ & $206 \mathrm{~m}$ & Autumn & hours outing \\
\hline 7 & Košice & $\begin{array}{l}48^{\circ} 43^{\prime} 21.8^{\prime \prime} \mathrm{N} \\
21^{\circ} 13^{\prime} 25.9^{\prime \prime} \mathrm{E}\end{array}$ & $297 \mathrm{~m}$ & Autumn & day pasture \\
\hline 8 & Brezno & $\begin{array}{l}48^{\circ} 39^{\prime} 59.99^{\prime \prime} \mathrm{N} \\
19^{\circ} 38^{\prime} 59.99^{\prime \prime} \mathrm{E}\end{array}$ & $900 \mathrm{~m}$ & Autumn & day/night pasture \\
\hline 9 & Lučenec & $\begin{array}{c}48^{\circ} 19^{\prime} 56.96^{\prime \prime} \mathrm{N} \\
19^{\circ} 40^{\prime} 1.49^{\prime \prime} \mathrm{E}\end{array}$ & $187 \mathrm{~m}$ & Summer & day pasture \\
\hline 10 & Liptovský Mikuláš & $\begin{array}{l}49^{\circ} 07^{\prime} 60.00^{\prime \prime} \mathrm{N} \\
19^{\circ} 30^{\prime} 59.99^{\prime \prime} \mathrm{E}\end{array}$ & $574 \mathrm{~m}$ & Summer & day/night pasture \\
\hline 11 & Liptovský Mikuláš & $\begin{array}{l}49^{\circ} 05^{\prime} 52.91^{\prime \prime} \mathrm{N} \\
19^{\circ} 36^{\prime} 20.09^{\prime \prime} \mathrm{E}\end{array}$ & $577 \mathrm{~m}$ & Summer & day pasture \\
\hline 12 & Ružomberok & $\begin{array}{l}49^{\circ} 04^{\prime} 29.28^{\prime \prime} \mathrm{N} \\
19^{\circ} 18^{\prime} 27.04^{\prime \prime} \mathrm{E}\end{array}$ & $481 \mathrm{~m}$ & Summer & hours outing \\
\hline 13 & Liptovský Mikuláš & $\begin{array}{l}49^{\circ} 05^{\prime} 21.3^{\prime \prime} \mathrm{N} \\
19^{\circ} 39^{\prime} 00.6^{\prime \prime} \mathrm{E}\end{array}$ & $624 \mathrm{~m}$ & Summer & day/night pasture \\
\hline 14 & Košice - okolie & $\begin{array}{l}48^{\circ} 36^{\prime} 51.41^{\prime \prime} \mathrm{N} \\
20^{\circ} 59^{\prime} 58.45^{\prime \prime} \mathrm{E}\end{array}$ & $209 \mathrm{~m}$ & Summer & day pasture \\
\hline 15 & Košice & $\begin{array}{l}48^{\circ} 39^{\prime} 54.6^{\prime \prime} \mathrm{N} \\
21^{\circ} 12^{\prime} 22.9^{\prime \prime} \mathrm{E}\end{array}$ & $273 \mathrm{~m}$ & Summer & day pasture \\
\hline 16 & Nitra & $\begin{array}{l}48^{\circ} 19^{\prime} 60.00^{\prime \prime} \mathrm{N} \\
18^{\circ} 12^{\prime} 60.00^{\prime \prime} \mathrm{E}\end{array}$ & $200 \mathrm{~m}$ & Summer & day pasture \\
\hline 17 & Levoča & $\begin{array}{l}49^{\circ} 00^{\prime} 60.00^{\prime \prime} \mathrm{N} \\
20^{\circ} 45^{\prime} 59.99^{\prime \prime} \mathrm{E}\end{array}$ & $463 \mathrm{~m}$ & Autumn & day pasture \\
\hline
\end{tabular}

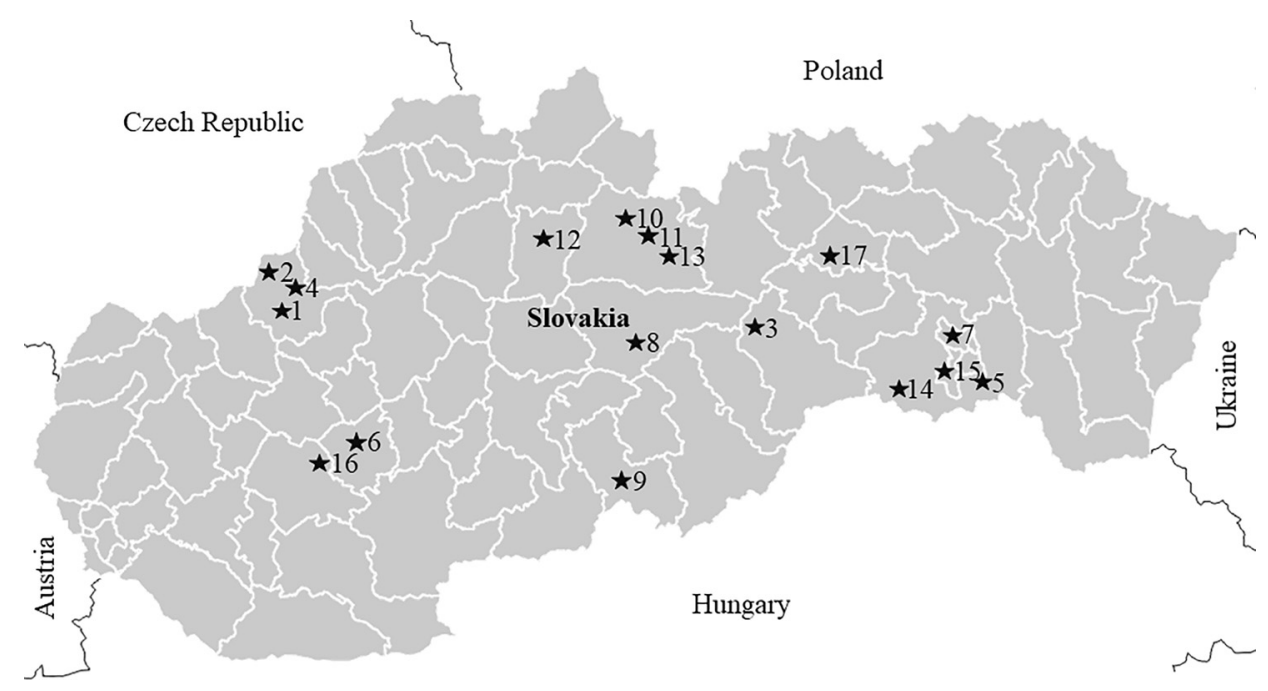

Fig. 1. Locations of the sampling sites. 1-17: numbers of horse studs 


\section{PCR analysis}

The molecular detection of $A$. phagocytophilum was attempted, based on an 839-bp fragment of the 16S rRNA gene, using specific primers designed in the Primer3plus software (F: 5'GCATGTAGGCGGTTCGGTAAGTT3' and R: 5'ATGGCGTGACGGGCAGTGT3'). The PCR reaction was performed in a total volume of $50 \mu \mathrm{L}$ of the reaction mixture containing $2 \mu \mathrm{L}$ of the tested DNA, $1.2 \mu \mathrm{L}$ of primers, $5.5 \mu \mathrm{L}$ of the PCR Master Mix (Jena Bioscience, Germany), $0.2 \mu \mathrm{L}$ of the Taq Polymerase (Jena Bioscience, Germany) and $41.5 \mu \mathrm{L}$ of the PCR Ultra $\mathrm{H}_{2} \mathrm{O}$ (Top Bio, Prague, Czech Republic). In each PCR assay, positive and negative controls were used. The PCR protocol consisted of the following steps: initial DNA denaturation for $2 \mathrm{~min}$ at $94{ }^{\circ} \mathrm{C}$ followed by the next 30 cycles, each consisting of denaturation at $94{ }^{\circ} \mathrm{C}$ for $30 \mathrm{~s}$, annealing at $51.2{ }^{\circ} \mathrm{C}$ for $30 \mathrm{~s}$ and extension at $72{ }^{\circ} \mathrm{C}$ for $1 \mathrm{~min}$, ending with a final extension at $72{ }^{\circ} \mathrm{C}$ for $10 \mathrm{~min}$ and the subsequent rapid cooling to $4{ }^{\circ} \mathrm{C}$. The PCR product was visualised on $1 \%$ agarose gel with Sybr Gold (Thermo Fisher Scientific, Waltham, MA, USA).

\section{Statistical analysis}

All statistical analyses were performed in the statistical analysis software GraphPad Prism, version 5.01 (GraphPad Software, Inc., San Diego, California, USA). The statistical comparison of categorical variables was carried out with the chi-square $\left(\chi^{2}\right)$ test or the Fisher's exact test, and $P$ values of less than 0.05 were considered significant. The differences in prevalence observed for individual sex and age categories of mares, stallions and geldings, respectively, were tested by the chi-square $\left(\chi^{2}\right)$ test.

\section{RESULTS}

Our results (Table 2) confirmed the presence of specific antibodies to A. phagocytophilum in 85 out of the 200 horses tested $(42.5 \%)$. The seropositivity rates identified in individual studs varied from $15.4 \%$ to $83.3 \%$. The differences between studs in antibody prevalence were not statistically significant $\left(\chi^{2}=17.40\right.$, $\left.\mathrm{df}=16, P=0.360\right)$.

The results of serological analyses by sex and age are shown in Table 3.

In our study, specific antibodies were observed in $46 / 108$ mares, 10/22 stallions and 29/70 geldings. The comparison of seroprevalence in animals by sex did not show significant differences $\left(\chi^{2}=0.1128, \mathrm{df}=2, P=0.946\right)$. The comparison of seroprevalence in individual age categories relative to sex did not show significant differences either. However, different results were obtained in the various age categories. In the category of less than three years, the sample size was too small to evaluate the chi-square test; for 3-10 years old animals, an insignificant difference, i.e. less than $0.05\left(\chi^{2}=0.755\right.$, df $\left.=2, P=0.686\right)$, was demonstrated. For the age category of more than 10 years, an insignificant prevalence, i.e. a $P$ value higher than $0.05\left(\chi^{2}=\right.$ 1.265 , df $=2, P=0.531$ ), was detected as well.

No positive PCR result was obtained at all.

Table 2. Results of screening for anti-Anaplasma phagocytophilum $\operatorname{IgG}$ antibodies by the indirect immunofluorescence assay in horses from selected regions in Slovakia

\begin{tabular}{|c|c|c|c|c|c|c|c|c|}
\hline \multirow{3}{*}{$\begin{array}{l}\text { Stud } \\
\text { number }\end{array}$} & \multirow{3}{*}{$\begin{array}{c}\text { Number of horses } \\
\text { tested }\end{array}$} & \multirow{2}{*}{\multicolumn{2}{|c|}{$\begin{array}{c}\text { Finally } \\
\text { negative titre } \\
\leq 1: 320\end{array}$}} & \multicolumn{3}{|c|}{ Tested titre } & \multirow{2}{*}{\multicolumn{2}{|c|}{$\begin{array}{l}\text { Finally positive } \\
\text { titre } \geq 1: 640\end{array}$}} \\
\hline & & & & $1: 80$ & $1: 160$ & $1: 320$ & & \\
\hline & & Number & $\%$ & animals & positive & positive & Number & $\%$ \\
\hline 1 & 15 & 10 & 66.7 & $7 / 15$ & $7 / 7$ & $5 / 7$ & 5 & 33.3 \\
\hline 2 & 10 & 5 & 50.0 & $6 / 10$ & $5 / 6$ & $5 / 6$ & 5 & 50.0 \\
\hline 3 & 20 & 11 & 55.0 & $13 / 20$ & $10 / 13$ & $10 / 13$ & 9 & 45.0 \\
\hline 4 & 12 & 8 & 66.7 & $4 / 12$ & $4 / 4$ & $4 / 4$ & 4 & 33.3 \\
\hline 5 & 13 & 9 & 69.2 & $7 / 13$ & $5 / 7$ & $5 / 7$ & 4 & 30.8 \\
\hline 6 & 19 & 14 & 73.7 & $9 / 19$ & $7 / 9$ & $5 / 9$ & 5 & 26.3 \\
\hline 7 & 10 & 6 & 60.0 & $5 / 10$ & $5 / 5$ & $4 / 5$ & 4 & 40.0 \\
\hline 8 & 20 & 10 & 50.0 & $15 / 20$ & $15 / 15$ & $12 / 15$ & 10 & 50.0 \\
\hline 9 & 5 & 3 & 60.0 & $2 / 5$ & $2 / 2$ & $2 / 2$ & 2 & 40.0 \\
\hline 10 & 6 & 1 & 16.7 & $5 / 6$ & $5 / 5$ & $5 / 5$ & 5 & 83.3 \\
\hline 11 & 11 & 5 & 45.5 & $8 / 11$ & $6 / 8$ & $6 / 8$ & 6 & 54.5 \\
\hline 12 & 13 & 11 & 84.6 & $3 / 13$ & $3 / 3$ & $3 / 3$ & 2 & 15.4 \\
\hline 13 & 4 & 2 & 50.0 & $3 / 4$ & $2 / 3$ & $2 / 3$ & 2 & 50.0 \\
\hline 14 & 9 & 6 & 66.7 & $7 / 9$ & $4 / 7$ & $3 / 7$ & 3 & 33.3 \\
\hline 15 & 21 & 8 & 38.1 & $16 / 21$ & $13 / 16$ & $13 / 16$ & 13 & 61.9 \\
\hline 16 & 7 & 4 & 57.1 & $5 / 7$ & $5 / 5$ & $3 / 5$ & 3 & 42.9 \\
\hline 17 & 5 & 2 & 40.0 & $3 / 5$ & $3 / 3$ & $3 / 3$ & 3 & 60.0 \\
\hline Total & 200 & 115 & 57.5 & $118 / 200$ & $101 / 118$ & $90 / 118$ & 85 & 42.5 \\
\hline
\end{tabular}


Table 3. Results of the serological analysis by sex and age $\mathrm{a}^{\mathrm{a}}$

\begin{tabular}{|c|c|c|c|c|c|c|c|c|}
\hline \multirow[b]{3}{*}{ Sex } & \multicolumn{2}{|c|}{ IFA, total } & \multicolumn{6}{|c|}{ IFA by age category } \\
\hline & \multirow[b]{2}{*}{ Negative } & \multirow[b]{2}{*}{ Positive } & \multicolumn{2}{|c|}{$<3$ years } & \multicolumn{2}{|c|}{$\geq 3<10$ years } & \multicolumn{2}{|c|}{$\geq 10$ years } \\
\hline & & & Negative & Positive & Negative & Positive & Negative & Positive \\
\hline Mares & 62 & 46 & 4 & 2 & 23 & 13 & 35 & 31 \\
\hline Stallions & 12 & 10 & 2 & 3 & 7 & 2 & 3 & 5 \\
\hline Geldings & 41 & 29 & 0 & 1 & 13 & 8 & 28 & 20 \\
\hline Total & 115 & 85 & 6 & 6 & 43 & 23 & 66 & 56 \\
\hline
\end{tabular}

PCR-positive samples were not found at all; IFA = indirect immunofluorescence assay.

\section{DISCUSSION}

In this paper we present the first multiregional study focused on the seroprevalence of A. phagocytophilum in the horse population of Slovakia. We confirmed a $42.5 \%$ prevalence of antibodies to $A$. phagocytophilum. Consistently with the results obtained by Rolim et al. (2015), no predisposition for infection based on the animal's sex or age was observed in our study, and no molecular evidence of A. phagocytophilum was found in the animals tested.

In Europe, a seropositivity higher than this was observed only in the Czech Republic (Praskova et al., 2011). In other European countries, seropositivity to A. phagocytophilum in horses has ranged between 16.7 and $22.75 \%$ until now (Egenvall et al., 2001; Leblond et al., 2005; Hansen et al., 2010; Passamonti et al., 2010; Ebani, 2019; Tsachev et al., 2019).

Similarly, different results were observed in Brazil as well. Nogueira et al. (2017) screened 97 blood samples from horses and $11.34 \%$ of them were seropositive to A. phagocytophilum. Similar results were presented by Dos Santos et al. (2019), with the seropositivity reaching $17.4 \%$. A higher seropositivity rate $(65 \%)$ was observed by Salvagni et al. (2010) in Brazilian horses.

In contrast to the previous data, a very low seroprevalence for A. phagocytophilum was detected in horses in Korea - 3.1\% (Lee et al., 2015) and in Canada - 0.53\% (Schvartz et al., 2015). There may be several reasons for these differences. One of them is the geographical variability of equine granulocytic anaplasmosis dependent on the tickfriendly environment (Janzén et al., 2019). Another reason may be the growing occurrence of this re-emerging disease worldwide. For example, Andersen et al. (2019) observed approximately twice as high $A$. phagocytophilum prevalence in the roe deer population as compared to the results obtained 14 years previously in Denmark (Skarphédinsson et al., 2005). Furthermore, such variation in the seropositivity levels may be caused by the use of different serological tests or horse management methods (Salvagni et al., 2010).

We suggest that the negative results obtained by molecular detection in this study may have been due the fact that none of the tested clinically healthy horses was in the acute phase of infection (Rejmanek et al., 2012). The acute phase is characterised by limited and short-term bacteraemia, while the peak antibody titre occurs between days 19 and 81 of infection and humoral immunity can persist for at least two years (Van Andel et al., 1998). On the other hand, while applying the PCR method, Passamonti et al. (2010) observed 11 horses positive for A. phagocytophilum in a group of 120 animals without any clinical signs, and none of the horses showed clinical or haematological changes typical of this disease. This can be regarded as one of the reasons why clinical anaplasmosis is still underdiagnosed.

The positive results of our serological analysis prove the circulation of A. phagocytophilum in Slovakian horses. Although it seems unlikely for the infected horses to serve as effective reservoirs of A. phagocytophilum (Sellon and Long, 2014), the infection was found to persist in experimentally infected horses for at least 129 days. Our data contribute to a better understanding of the potential occurrence and spread of this disease and facilitate the identification of new sites with a higher risk of $A$. phagocytophilum infection.

Anaplasmosis is an re-emerging zoonotic disease with a natural cycle. Due to the non-specific clinical signs and/or the frequently subclinical course of anaplasmosis in both animals and humans, it is important to include this disease in the differential diagnosis of vector-borne encephalitis for animals as well as humans. The results of this serological survey indicate that anaplasmosis can be common in horses. In view of the One Health concept, the results can significantly contribute to improving the knowledge of the epidemiological situation and serve as a basis for successful diagnosis and risk assessment in this region of Central Europe.

\section{ACKNOWLEDGEMENTS}

This work was supported by IGA UVLF $04 / 2018$ and by the Ministry of Education, Science, Research and Sport of the Slovak Republic through the project KEGA 014UVLF-4/2019.

\section{REFERENCES}

Andersen, N. S., Larsen, S. L., Olesen, C. R., Stiasny, K., Kolmos, H. J., Jensen, P. M. and Skarphédinsson, S. (2019): Continued expansion of tick-borne pathogens: tick-borne encephalitis virus complex and Anaplasma phagocytophilum in Denmark. Ticks Tick Borne Dis. 10, 115-123.

Bastos, A. D. S., Mohammed, O. B., Bennett, N. C., Petevinos, C. and Alagaili, A. N. (2015): Molecular detection of novel Anaplasmataceae closely related to Anaplasma platys and Ehrlichia canis in the dromedary camel (Camelus dromedarius). Vet. Microbiol. 179, 310-314. 
Bazovska, S., Machacova, E., Spalekova, M. and Kontrosova, S. (2005): Reported incidence of Lyme disease in Slovakia and antibodies to B. burgdorferi antigens detected in healthy population. Bratisl. Lek. Listy 106, 270-273.

Bermann, F., Davoust, B., Fournier, P. E., Brisou-Lapointe, A. V. and Brouqui, P. (2002): Ehrlichia equi (Anaplasma phagocytophila) infection in an adult horse in France. Vet. Rec. 150, 787-788.

Butler, C. M., Sloet van Oldruitenborgh-Oosterbaan, M. M., Werners, A. H., Stout, T. A. E., Nielen, M., Jongejan, F., van der Kolk, J. H. and Houwers, D. J. (2016): Borrelia burgdorferi and Anaplasma phagocytophilum in ticks and their equine hosts: A prospective clinical and diagnostic study of 47 horses following removal of a feeding tick. Pferdeheilkunde 32, 335-345.

Dahmani, M., Davoust, B., Tahir, D., Raoult, D., Fenollar, F. and Mediannikov, O. (2017): Molecular investigation and phylogeny of Anaplasmataceae species infecting domestic animals and ticks in Corsica, France. Parasit. Vectors 10, 302.

Dantas-Torres, F. and Otranto, D. (2017): Anaplasmosis. In: Marcondes, C. B. (ed.) Arthropod Borne Diseases. Springer, Cham. Chapter 15, pp. 215-222.

Derdáková, M., Halánová, M., Stanko, M., Štefančíková, A., Čisláková, L. and Peťko, B. (2003): Molecular evidence for Anaplasma phagocytophilum and Borrelia burgdorferi sensu lato in Ixodes ricinus ticks from eastern Slovakia. Ann. Agric. Environ. Med. 10, 269-271.

Derdáková, M., Štefančíková, A., Špitalská, E., Taragelová, V., Koštálová, T., Hrklová, G., Kybicová, K., Schánilec, P., Majláthová, V., Várady, M. and Pet́ko, B. (2011): Emergence and genetic variability of Anaplasma species in small ruminants and ticks from Central Europe. Vet. Microbiol. 153, 293-298.

Dos Santos, T. M., Roier, E. C. R., Pires, M. S., Santos, H. A., Vilela, J. A. R., Peckle, M., Paulino, P. G., Baldani, C. D. and Massard, C. L. (2019): Molecular evidence of Anaplasma phagocytophilum and Theileria equi coinfections in horses from Rio de Janeiro, Brazil. Vet. Anim. Sci. 7, 100055.

Dumler, J. S., Barbet, A. F., Bekker, C. P., Dasch, G. A., Palmer, G. H., Ray, S. C., Rikihisa, Y. and Rurangirwa, F. R. (2001): Reorganization of genera in the families Rickettsiaceae and Anaplasmataceae in the order Rickettsiales: unification of some species of Ehrlichia with Anaplasma, Cowdria with Ehrlichia and Ehrlichia with Neorickettsia, descriptions of six new species combinations and designation of Ehrlichia equi and 'HGE agent' as subjective synonyms of Ehrlichia phagocytophila. Int. J. Syst. Evol. Microbiol. 51, 2145-2165.

Ebani, V. V. (2019): Serological evidence of Anaplasma phagocytophilum and spotted fever group Rickettsia spp. exposure in horses from Central Italy. Pathogens 8, 88.

Egenvall, A., Franzén, P., Gunnarsson A., Engvall, E. O., Vågsholm, I., Wikström, U-B. and Artursson, K. (2001): Cross-sectional study of the seroprevalence to Borrelia burgdorferi sensu lato and granulocytic Ehrlichia spp. and demographic, clinical and tickexposure factors in Swedish horses. Prev. Vet. Med. 49, 191-208.

Ehounoud, C. B., Yao, K. P., Dahmani, M., Achi, Y. L., Amanzougaghene, N., N'Douba, A. K., N'Guessan, J. D., Raoult, D., Fenollar, F. and Mediannikov, O. (2016): Multiple pathogens including potential new species in tick vectors in Côte d'Ivoire. PLOS Negl. Trop. Dis. 10, e0004367.
Eisen, L. (2018): Pathogen transmission in relation to duration of attachment by Ixodes scapularis ticks. Ticks Tick Borne Dis. 9, 535-542.

Franzén, P., Aspan, A., Egenvall, A., Gunnarsson, A., Åberg, L. and Pringle, J. (2005): Acute clinical, hematological, serologic, and polymerase chain reaction findings in horses experimentally infected with a European strain of Anaplasma phagocytophilum. J. Vet. Intern. Med. 19, 232-239.

Greene, C. E. (2012): Infectious Diseases of the Dog and Cat. 4th edition. Elsevier Inc., St. Louis, Mo., 1354 pp.

Guo, W-P., Tian, J-H., Lin, X-D., Ni, X-B., Chen, X-P., Liao, Y., Yang, S-Y., Dumler, S., Holmes, E. C. and Zhang, Y-Z. (2016): Extensive genetic diversity of Rickettsiales bacteria in multiple mosquito species. Sci. Rep. 6, 38770.

Hansen, M. G. B., Christoffersen, M., Thuesen, L. R., Petersen, M. R. and Bojesen, A. M. (2010): Seroprevalence of Borrelia burgdorferi sensu lato and Anaplasma phagocytophilum in Danish horses. Acta Vet. Scand. 52, 49.

Jahfari, S., Coipan, E. C., Fonvile, M., van Leeuwen, A. D., Hengeveld, P., Heylen, D., Heyman, P., van Maanen, C., Butler, C. M., Földvári, G., Szekeres, S., van Duijvendijk, G., Tack, W., Rijks, J. M., van der Giessen, J., Takken, W., van Wieren, S. E., Takumi, K. and Sprong, H. (2014): Circulation of four Anaplasma phagocytophilum ecotypes in Europe. Parasit. Vectors 7, 365.

Janzén, T., Petersson, M., Hammer, M., Aspán, A. and Dinnétz, P. (2019): Equine granulocytic anaplasmosis in Southern Sweden: Associations with coniferous forest, water bodies and landscape heterogeneity. Agric. Ecosyst. Environ. 285, 106626.

Kalinová, Z., Halánová, M., Čisláková, L., Juriš, P. and Čechová, L. (2015): Occurrence of antibodies to Anaplasma phagocytophilum in patients with suspected tick-borne encephalitis. Ann. Agric. Environ. Med. 22, 409-411.

Kalinová, Z., Halánová, M., Čisláková, L., Sulinová, Z. and Jarčuška, P. (2009): Occurrence of IgG antibodies to Anaplasma phagocytophilum in humans suspected of Lyme borreliosis in eastern Slovakia. Ann. Agric. Environ. Med. 16, 285-288.

Kiewra, D., Zaleśny, G. and Czułowska, A. (2014): The prevalence of Anaplasma phagocytophilum in questing Ixodes ricinus ticks in SW Poland. Pol. J. Microbiol. 63, 89-93.

Kozak, J., Ostapowicz, K., Bytnerowicz, A. and Wyzga, B. (2013): The Carpathians: Integrating Nature and Society Towards Sustainability. Springer, Berlin, Germany. 653 pp.

Król, N., Obiegala, A., Pfeffer, M., Lonc, E. and Kiewra, D. (2016): Detection of selected pathogens in ticks collected from cats and dogs in the Wrocław Agglomeration, South-West Poland. Parasit. Vectors 9, 351.

Leblond, A., Pradier, S., Ptel, P. H., Fortier, G., Boireau, P., Chadoeuf, J. and Sabatier, P. (2005): Epidemiological investigations on equine anaplasmosis (Anaplasma phagocytophilum) in South France [in French]. Rev. Sci. Tech. 24, 899-908.

Lee, S. H., Kim, K. T., Yun, S. H., Choi, E., Lee, G. H., Park, Y. S., Cho, K. H., Yi, S., Kwon, O. D., Kim, T. H. and Kwak, D. (2015): Serological and molecular detection of Anaplasma phagocytophilum in horses reared in Korea. Vet. Med. 60, 533-538.

Lotrič-Furlan, S., Rojko, T., Petrovec, M., Avšič-Županc, T. and Strle, F. (2006): Epidemiological, clinical and laboratory characteristics of patients with human granulocytic anaplasmosis in Slovenia. Wien Klin. Wochenschr. 118, 708-713. 
Lu, M., Tian, J-H., Yu, B., Guo, W-P., Holmes, E. C. and Zhang, YZ. (2017): Extensive diversity of Rickettsiales bacteria in ticks from Wuhan, China. Ticks Tick Borne Dis. 8, 574-580.

Mullen, G. R. and Durden, L. A. (2018): Medical and Veterinary Entomology. 3rd edition. Elsevier Inc., London. 769 pp.

Nogueira, R. M. S., Silva, A. B., Sato, T. P., de Sá, J. C., dos Santos, A. C. G., Filho, E. F. A., do Vale, T. L. and Gazêta, G. S. (2017): Molecular and serological detection of Theileria equi, Babesia caballi and Anaplasma phagocytophilum in horses and ticks in Maranhão, Brazil. Pesq. Vet. Bras. 37, 1416-1422.

Nováková, M., Víchová, B., Majláthová, V., Lesñáková, A., Pochybová, M. and Pet'ko, B. (2010): First case of human granulocytic anaplasmosis from Slovakia. Ann. Agric. Environ. Med. 17, 173-175.

Onderka, M., Pecho, J. and Nejedlík, P. (2020): On how rainfall characteristics affect the sizing of rain barrels in Slovakia. J. Hydrol. Reg. Stud. 32, 100747.

Parham, P. E., Waldock, J., Christophides, G. K., Hemming, D., Agusto, F., Evans, K. J., Fefferman, N., Gaff, H., Gumel, A., LaDeau, S., Lenhart, S., Mickens, R. E., Naumova, E. N., Ostfeld, R. S., Ready, P. D., Thomas, M. B., Velasco-Hernandez, J. and Michael, E. (2015): Climate, environmental and socio-economic change: weighing up the balance in vector-borne disease transmission. Philos. Trans. R. Soc. Lond. B Biol. Sci. 370, 1-17.

Passamonti, F., Veronesi, F., Cappelli, K., Capomaccio, S., Coppola, G., Marenzoni, M. L., Piergili, F. D., Verini, S. A. and Coletti, M. (2010): Anaplasma phagocytophilum in horses and ticks: A preliminary survey in Central Italy. Comp. Immunol. Microbiol. Infect. Dis. 33, 78-83.

Pishmisheva, M., Baymakova, M., Tsachev, I. and Christova, I. (2016): Ehrlichioses and anaplasmoses. Gen. Med. 18, 66-72.

Praskova, I., Bezdekova, B., Zeman, P. and Jahn, P. (2011): Seroprevalence of Anaplasma phagocytophilum in horses in the Czech Republic. Ticks Tick Borne Dis. 2, 111-115.

Rejmanek, D., Foley, P., Barbet, A. and Foley, J. (2012): Evolution of antigen variation in the tick-borne pathogen Anaplasma phagocytophilum. Mol. Biol. Evol. 29, 391-400.

Rolim, M. F., Oliveira, F. C. R., Graca, F. A. S. and Brasil, F. C. (2015): Serological evidence of exposure to Anaplasma phagocytophilum in horses from the Rio de Janeiro state mounted police bred in the urban zone. Ciên. Anim. Bras. 16, 377-387.

Rymaszewska, A. and Grenda, S. (2008): Bacteria of the genus Anaplasma - characteristics of Anaplasma and their vectors: a review. Vet. Med. 53, 573-584.

Salvagni, C. A., Dagnone, A. S., Gomes, T. S., Mota, J. S., Andrade, G. M., Baldani, C. D. and Machado, R. Z. (2010): Serologic evidence of equine granulocytic anaplasmosis in horses from central West Brazil. Rev. Bras. Parasitol. Vet. Jaboticabal 19, 135-140.

Schvartz, G., Epp, T., Burgess, H. J., Chilton, N. B., Pearl, D. L. and Lohmann, K. L. (2015): Seroprevalence of equine granulocytic anaplasmosis and Lyme borreliosis in Canada as determined by a point-of care enzyme-linked immunosorbent assay (ELISA). Can. Vet. J. 56, 575-580.
Sellon, D. C. and Long, M. T. (2014): Anaplasma phagocytophilum infection. In: Sellon, D. C. and Long, M. T. (eds) Equine Infectious Diseases. $2^{\text {nd }}$ edition. Saunders/Elsevier, St. Louis, Missouri. pp. 344-347.

Skarphédinsson, S., Jensen, P. M. and Kristiansen, K. (2005): Survey of tick-borne infections in Denmark. Emerg. Infect. Dis. 11, 1055-1061.

Slivinska, K., Víchova, B., Werszko, J., Szewczyk, T., Wróblewski, Z., Pet'ko, B., Ragač, O., Demeshkant, V. and Karbowiak, G. (2016): Molecular surveillance of Theileria equi and Anaplasma phagocytophilum infections in horses from Ukraine, Poland and Slovakia. Vet. Parasitol. 215, 35-37.

Smetanová, K., Schwarzová, K. and Kocianová, E. (2006): Detection of Anaplasma phagocytophilum, Coxiella burnetti, Rickettsia spp., and Borrelia burgdorferi s. l. in ticks, and wild-living animals in Western and Middle Slovakia. Ann. N. Y. Acad. Sci. 1078, 312-315.

Svitálková, Z., Haruštiaková, D., Mahríková, L., Berthová, L., Slovák, M., Kocianová, E. and Kazimírová, M. (2015): Anaplasma phagocytophilum prevalence in ticks and rodents in an urban and natural habitat in South-Western Slovakia. Parasit. Vectors 8, 276.

Tate, C. M., Howerth, E. W., Mead, D. G., Dugan, V. G., Luttrell, P. M., Sahora, A. I., Munderloh, U. G., Davidson, W. R. and Yabsley, M. J. (2013): Anaplasma odocoilei sp. nov. (family Anaplasmataceae) from white-tailed deer (Odocoileus virginianus). Ticks Tick Borne Dis. 4, 110-119.

Tomassone, L., Berriatua, E., De Sousa, R., Duscher, G. G., Mihalca, A. D., Silaghi, C., Sprong, H. and Zintl, A. (2018): Neglected vectorborne zoonoses in Europe: Into the wild. Vet. Parasitol. 251, 17-26.

Tsachev, I., Baymakova, M. and Pantchev, N. (2019): Seroprevalence of Anaplasma phagocytophilum, Ehrlichia spp. and Borrelia burgdorferi infections in horses: first report from Northern Bulgaria - Short communication. Acta Vet. Hung. 67, 197-203.

Tsachev, I., Pantchev, N., Marutsov, P., Petrov, V., Gundasheva, D. and Baymakova, M. (2018): Serological evidence of Borrelia burgdorferi, Anaplasma phagocytophilum and Ehrlichia spp. infections in horses from Southeastern Bulgaria. Vector Borne Zoonotic Dis. 18, 588-594.

Van Andel, A. E., Maganrelli, L. A., Heimer, R. and Wilson, M. L. (1998): Development and duration of antibody response against Ehrlichia equi in horses. J. Am. Vet. Med. Assoc. 212, 1910-1914.

Vanstreels, R. E. T., Yabsley, M. J., Parsons, N. J., Swanepoel, L. and Pistorius, P. A. (2018): A novel candidate species of Anaplasma that infects avian erythrocytes. Parasit. Vectors 11, 525.

Woldehiwet, Z. (2010): The natural history of Anaplasma phagocytophilum. Vet. Parasitol. 167, 108-122.

Yang, J., Han, R., Niu, Q., Liu, Z., Guan, G., Liu, G., Luo, J. and Yin, H. (2018): Occurrence of four Anaplasma species with veterinary and public health significance in sheep, northwestern China. Ticks Tick Borne Dis. 9, 82-85.

Yang, J., Li, Y., Liu, Z., Liu, J., Niu, Q., Ren, Q., Chen, Z., Guan, G., Luo, J. and Yin, H. (2015): Molecular detection and characterisation of Anaplasma spp. in sheep and cattle from Xinjiang, northwest China. Parasit. Vectors 8, 108.

Open Access. This is an open-access article distributed under the terms of the Creative Commons Attribution-NonCommercial 4.0 International License (https:// creativecommons.org/licenses/by-nc/4.0/), which permits unrestricted use, distribution, and reproduction in any medium for non-commercial purposes, provided the original author and source are credited, a link to the CC License is provided, and changes - if any - are indicated. 